\title{
Release of chicken luteinising hormone-releasing hormone-I (cLHRH-I) by mediobasal hypothalamus in the cockerel: validation of an incubation system and effect of excitatory amino acids
}

\author{
JM Jacquet ${ }^{1 *}$, A Robinson $^{2}, \mathrm{M} \mathrm{Caldani}^{3}$ \\ 1 INRA, Recherches Avicoles, Centre de Tours, 37380 Nouzilly, France; \\ 2 Dept of Physiology and Biochemistry, University of Reading, Whiteknights, \\ Reading RG6 2AJ, UK; \\ 3 INRA, Physiologie de la Reproduction, Centre de Tours, 37380 Nouzilly, France
}

(Received 29 March 1993; accepted 16 February 1994)

\begin{abstract}
Summary - An in vitro system for the incubation of mediobasal hypothalami (MBH) of cockerels and a radioimmunoassay for chicken luteinising hormone-releasing hormone-I (CLHRH-I) were developed. The size of the hypothalamic fragment (MBH including the median eminence) and the incubation conditions used $\left(40^{\circ} \mathrm{C}\right.$, under constant shaking and gassing) preserved the physiological properties of the tissue. It was possible to maintain the $\mathrm{MBH}$ in vitro and to study the LHRH release for several hours. The assay proved sensitive enough $\left(\mathrm{ED}_{80}=0.794 \mathrm{pmol} / \mathrm{tube}\right.$, ie $\left.4.59 \mathrm{pg} / \mathrm{ml}\right)$ and sufficiently precise (within-assay coefficient of variation $=4.4 \%$ and between-assay coefficient of variation $=10.2 \%$ ) to measure the amounts of peptide released in the incubation medium. The use of this incubation system provided the first evidence of the stimulating effect of the excitatory amino acids glutamate, NMDA and kainate on the secretion of $\mathrm{CLHRH}-\mathrm{I}$ in birds. Our results suggest that the effect on the NMDA receptor is predominant.
\end{abstract}

chicken LHRH / hypothalamus / incubation / excitatory amino acids

Résumé - Sécrétion de chicken luteinising hormone-releasing hormone-l (cLHRH-I) par I'hypothalamus médiobasal chez le coq : validation d'un système d'incubation et effet des acides aminés excitateurs. Un système d'incubation in vitro d'hypothalamus médiobasal (HMB) de coq et un dosage radioimmunologique de la chicken luteinising hormone-releasing hormone-1 (cLHRH-I) ont été développés. La taille du fragment hypothalamique prélevé (HMB comprenant l'éminence médiane) et les conditions d'incubation utilisées $\left(40^{\circ} \mathrm{C}\right.$, sous agitation et oxygénation constantes) respectent les propriétés physiologiques du tissu. Ils ont permis de le maintenir in vitro

* Present address: National Avian Research Center, Sweihan PO Box 9903, Abu Dhabi, United Arab Emirates 
et d'étudier la sécrétion de CLHRH-I pendant plusieurs heures. Le dosage s'est révélé suffisamment sensible ( $E D 80=0,794$ pmole/tube, c'est-à-dire $4,59 \mathrm{pg} / \mathrm{ml}$ ) et précis (coefficient de variation intradosage $=4,4 \%$ et coefficient de variation interdosages $=10,2 \%$ ) pour mesurer de façon fiable les quantités de neuropeptide libérées dans le milieu d'incubation. L'utilisation de ce système a permis de mettre en évidence pour la première fois chez les oiseaux l'effet stimulateur des acides aminés excitateurs : glutamate, NMDA et kainate sur la sécrétion de cLHRH-I. Les résultats obtenus suggèrent un effet prédominant sur le récepteur NMDA.

\section{poulet-LHRH / hypothalamus / incubation / acides aminés excitateurs}

\section{INTRODUCTION}

The release of luteinising hormone-releasing hormone ( $\mathrm{LHRH}$ ) by hypothalamic neuron terminals at the level of the median eminence is one of the major regulating steps of reproductive function and the direct measurement of the secretion of LHRH is required for the understanding of reproductive physiology. Thus, several in vivo (Levine and Ramirez, 1986, in the rat; Caraty and Locatelli, 1988, in the ram) and in vitro (review in Wibullaksanakul and Handelsman, 1991) techniques have been developed. The in vitro approach has the advantage of allowing the direct testing of the effect of various substances on the secretion. Two types of in vitro methods have been described: superfusion (Gallardo and Ramirez, 1977, in the rat; Knight, 1983, in the chicken) and static incubation (Rotsztejn et al, 1976, in the rat; Katz et al, 1990, in the chicken). Wibullaksanakul and Handelsman (1991) compared both systems in a systematic study and concluded the superiority of static incubation, which they judge technically simpler, more robust and accurate than superfusion. With the aim of studying the regulation of $\mathrm{LHRH}$ secretion in the chicken, we have developed an incubation system for chicken mediobasal hypothalamus (MBH) and a radioimmunoassay sensitive enough for reliable measurement of the amounts of chicken LHRH-I released in vitro. Indeed, from the 2 forms of $L H R H$ known in the chicken, chicken LHRH-I
(cLHRH-I) (King and Millar, 1982a,b) and chicken LHRH-II (cLHRH-II) (Miyamoto et al, 1984), only cLHRH-I has been shown to be released from the median eminence (Katz et al, 1990). Both techniques were validated. To validate the incubation technique, the effect of potassium and calcium on the in vitro secretion of $\mathrm{CLHRH}-\mathrm{I}$ was studied. The system was then used to investigate the action of excitatory amino acids (EAAs) on LHRH release, not yet documented in birds.

\section{MATERIALS AND METHODS}

\section{Animals}

Adult cockerels (meat-type breeders, T55, SASSO) were housed in individual cages under a photoschedule of $16 \mathrm{~L}: 8 \mathrm{D}$. Food was restricted to $100 \mathrm{~g}$ per $\mathrm{d}$ as recommended for meat-type breeders and water was available ad libitum.

\section{Hypothalamic tissue}

Birds were killed by cervical dislocation without anesthesia. Hypothalamic fragments including $\mathrm{MBH}$ and the median eminence were rapidly dissected using the posterior border of the supraoptic decussatio as the anterior limit and the root of the oculomotor nerves as the posterior limit. The fragments dissected extended laterally $1 \mathrm{~mm}$ from the third ventricule. Such fragments exclusively contain the nerve terminals of $\mathrm{CLHRH}-\mathrm{I}$ neurons. The cell-bodies of these neurons are 
located in the preoptic and septal areas (Sterling and Sharp, 1982; Józsa and Mess, 1982). The CLHRH-II cell bodies are situated in the oculomotor complex of the midbrain and they do not seem to project to the median eminence and no fibres were detected in the hypothalamus (Mikami et al, 1988; Kuenzel and Blhäser, 1991). The $\mathrm{MBH}$ were maintained in oxygenated artificial avian cerebrospinal fluid (ACSF) on ice during collection. ACSF was prepared immediately prior to the experiment (for composition, see Knight, 1983). Bacitracin (300 mg/l) was added to inhibit the activity of endogenous peptidase.

\section{Static incubation system}

One $\mathrm{MBH}$ was placed in each glass tube containing $500 \mu \mathrm{l}$ ACSF. The tubes were incubated in a warmed $\left(40^{\circ} \mathrm{C}\right)$ water-bath with shaking $(50$ cycles/min). Each tube was individually gassed with $95 \% \mathrm{O}_{2} / 5 \% \mathrm{CO}_{2}$ throughout the incubation. A preincubation period of $1 \mathrm{~h}$ was observed to allow stabilisation of the basal release of $\mathrm{GnRH}$. The incubation medium was collected and replaced with $500 \mu \mathrm{l}$ fresh medium every $30 \mathrm{~min}$ without further washing of the tissue. Collected fractions were stored frozen at $-20^{\circ} \mathrm{C}$ until cLHRH-I concentration was measured.

\section{Production of antibody to cLHRH-I}

Synthetic cLHRH ([Gln8]) GnRH, Peninsula Laboratories Ltd, St Helens, Merseyside, UK) was conjugated with human serum albumin (HSA) using the carbodiimide method (Fraser et al, 1974). Peptide $(8 \mathrm{mg})$ was mixed with $91.6 \mathrm{mg}$ HSA (Sigma) and $80 \mathrm{mg}$ 3-(3-dimethylaminopropyl)carbodiimide (Sigma). After shaking for 7 $h$, the peptide-protein conjugate was separated by dialysis against $0.01 \%$ mercaptoethanol, with several changes, for $48 \mathrm{~h}$.

Rabbits were immunized by intra-dermal injection with the CLHRH-I conjugate homogenized with complete Freund's adjuvant. Four successive injections were performed at 7-d intervals. An iv booster injection, using Phénergan ${ }^{(1)}$ (promethazine) as anti-histaminic agent, was administered 4 weeks after the last injection and was followed by several booster injections at regular intervals. After a final booster injection, one antiserum (516/13) proved suitable for measurement of $\mathrm{CLHRH}-\mathrm{I}$ release in vitro.

\section{Radioiodination of $\mathrm{CLHRH-I}$}

Synthetic CLHRH-I was labelled with 125 I using the iodogen method (Salacinski et al, 1979). lodogen $(5 \mu \mathrm{g}$, evaporated to dryness in a polypropylene tube) was used with $5 \mu \mathrm{g} \mathrm{CLHRH}$ I diluted in $0.01 \mathrm{M} \mathrm{PBS}$ and $0.5 \mathrm{mCi}$ [ ${ }^{125}$ ] $-\mathrm{Nal}$ (IMS 30, Amersham, France). After an incubation of $15 \mathrm{~min}$, the reaction was stopped by adding $100 \mu \mathrm{l}$ PBS. The labelled peptide was purified using a method adapted from Knight (1983). After a first separation of free iodine on Dowex-resin (1 $x$ 8-400, Sigma), the final purification was performed on a $0.7 \times 15 \mathrm{~cm}$ carboxymethylcellulose (Sigma) column equilibrated with $0.002 \mathrm{M}$ ammonium acetate $(\mathrm{pH} 4.5)$. Fourteen fractions $(2 \mathrm{ml})$ were eluted with $0.002 \mathrm{M}$ ammonium acetate and 10 further fractions with $0.06 \mathrm{M}$ ammonium acetate. The $\mathrm{cLHRH}-\mathrm{I}$ fraction displaying the highest activity was used for the assays.

\section{Radioimmunoassay of cLHRH-I}

Dilute samples (0.01 M PBS, 0.025 M EDTA, $0.05 \%$ bovine serum albumin and $0.01 \%$ azide) were assayed in duplicate following an assay procedure adapted from Knight (1983). Samples were incubated $24 \mathrm{~h}$ at $4^{\circ} \mathrm{C}$ in the presence of antiserum $516 / 13$ at the final dilution of $1 / 180000$ $(\mathrm{B} / \mathrm{T}=35 \%)$. The labelled hormone $(10000$ $\mathrm{cpm} /$ tube) was added on the 2nd day and tubes were incubated $48 \mathrm{~h}$ at $4^{\circ} \mathrm{C}$. On the 4 th day, the sheep anti-rabbit immunoglobulin was added with normal rabbit serum and polyethylene glycol. After 45 min of incubation, the tubes were centrifuged, the supernatant aspirated and the radioactivity of the pellets counted with a gamma counter. The specificity, sensitivity and precision of the assay were determined.

\section{Validation of the incubation system}

The effect of depolarization on the release of $\mathrm{CLHRH}-\mathrm{I}$ was studied on a group of $4 \mathrm{MBH}$. The depolarization was achieved by a 10 -fold increase of the concentration of potassium from 6.4 to 64 
$\mathrm{mM}$. The resulting increase in cations was compensated by the decrease of the concentration of sodium (from 126.1 to $68.5 \mathrm{mM}$ ). Six 30-min fractions were collected with the potassium being increased in the 30-60 and 150-180 min fractions.

The dose-response relationship of the potassium-induced release of $\mathrm{CLHRH}-\mathrm{I}$ was studied on 4 groups of $4 \mathrm{MBH}$. Two 30-min incubation periods were observed. The $\mathrm{MBH}$ were incubated with ACSF containing $6.4 \mathrm{mM}$ potassium for the first $30 \mathrm{~min}$ and with $32 \mathrm{mM}, 48 \mathrm{mM}, 56 \mathrm{mM}$ or 64 $\mathrm{mM}$ potassium for the second $30 \mathrm{~min}$ incubation period. In subsequent experiments the submaximal dose of $56 \mathrm{mM}$ was used.

The effect of the absence of calcium in ACSF on the $56 \mathrm{mM}$ potassium-induced release was studied on 2 further groups of $4 \mathrm{MBH}$. The basal release $(6.4 \mathrm{mM}$ potassium) was measured in the first incubation fraction. During the second period, the first group of $\mathrm{MBH}$ was incubated with $56 \mathrm{mM}$ potassium ACSF containing $3 \mathrm{mM}$ calcium, while the second group was incubated with $56 \mathrm{mM}$ potassium without calcium. In this group, the calcium ions were replaced by magnesium ions and EDTA was added to ACSF.

\section{Effect of EAA on the release of $C L H R H-I$ in vitro}

The release of $\mathrm{CLHRH}-\mathrm{I}$ was evaluated in the presence of $100 \mu \mathrm{M}$ glutamate (GLU) and $100 \mu \mathrm{M} \mathrm{N}$ methyl-D-aspartate (NMDA). Two groups of $4 \mathrm{MBH}$ were used. Two 30-min incubation periods were used. The basal release of $\mathrm{CLHRH}-\mathrm{I}$ was determined during the first incubation period and the effect of the 2 EAA in the second.

The effect of increasing doses $(1 \mu \mathrm{M}, 10 \mu \mathrm{M}$, $100 \mu \mathrm{M})$ of NMDA and kainic acid (KA) were studied. Two groups of $4 \mathrm{MBH}$ were used. Fractions were collected every $30 \mathrm{~min}$. The doses were applied at 1.5-h intervals. Each stimulation with EAA was preceded by a basal release fraction, and followed by a washing fraction which was not collected.

\section{Statistical analysis}

Within-treatment comparisons were performed by a paired $t$ test and between treatment comparisons by a $t$ test.

\section{RESULTS}

\section{Validation of the radioimmunoassay for CLHRH-I}

The study in our cLHRH-I radioimmunoassay system, using antiserum $516 / 13$, of the immunoreactivity of increasing concentrations of several hypothalamic peptides revealed $100 \%$ cross-reaction with mammalian LHRH and $20 \%$ cross-reaction with chicken LHRH-II. No cross-reaction could be detected with leucine-enkephalin, methionin-enkephalin, thyrotropin-releasing hormone (TRH) and corticotropin-releasing factor (CRF) up to a concentration of 10 $\mu \mathrm{g} / \mathrm{ml}$, ie between 1 and $10 \mu \mathrm{M}$. The dose that inhibited the binding of the radiolabelled hormone by $50 \%\left(E D_{50}\right)$ was $4.85 \mathrm{pg} /$ tube, ie a concentration of $24.25 \mathrm{pg} / \mathrm{ml}$. The limit of sensitivity of the assay, expressed as the dose that inhibited the binding of the radiolabelled hormone by $20 \%\left(E D_{80}\right)$ was 0.916 $\mathrm{pg} / \mathrm{tube}$, ie $4.58 \mathrm{pg} / \mathrm{ml}$. The immunoreactivity of serial dilutions of hypothalamic extracts from cockerels proved parallel to the standard curve. The intra- and interassay coefficients of variation were, 4.4 and $10.2 \%$, respectively.

\section{Validation of the incubation system}

The depolarization induced by $64 \mathrm{mM}$ potassium elicited an 8-fold increase $(P<0.01)$ in CLHRH-I release (fig 1 ). The second depolarization occurring $2 \mathrm{~h}$ later induced an equivalent increase $(P<0.01)$ in the secretion of the peptide. Experiment 2 showed that the depolarization-induced release of CLHRH-I was dose-dependent (fig 2a). Each concentration of potassium elicited a significant increase (compared with basal release) in the secretion $(P<0.05$ for 32 $\mathrm{mM}$ and $P<0.01$ for the other 3 concentrations). The omission of calcium ions in 


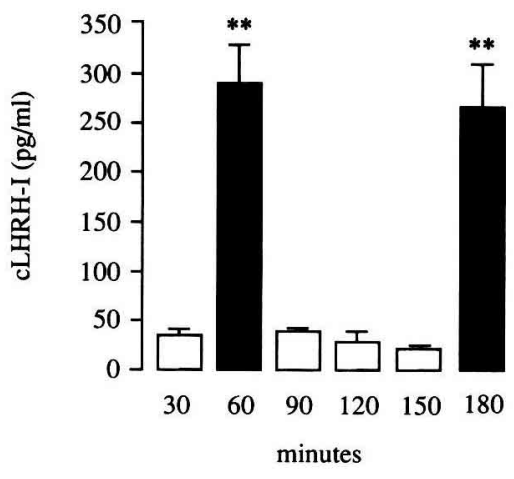

Fig 1. Effect of depolarization achieved by a 10fold increase in the concentration of potassium ion on the release of cLHRH-l by incubated MBH in cockerels. The MBH were exposed to ACSF containing $64 \mathrm{mM}$ potassium for 2 collection periods at 2-h intervals (white bars: $6.4 \mathrm{mM}$ potassium; black bars: $64 \mathrm{mM}$ potassium). Fractions were collected every $30 \mathrm{~min}$. Values are mean $\pm \operatorname{sem}(n=4) .{ }^{*} P<0.01$ compared with immediately preceding basal release.

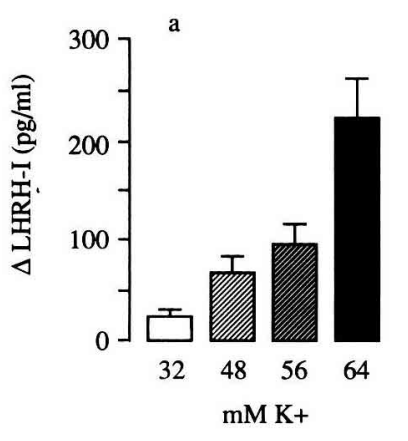

\section{b}

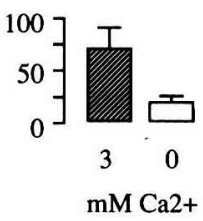

Fig 2. a) Effect of several concentrations of potassium on the release of $\mathrm{CLHRH}-\mathrm{I}$ by incubated $\mathrm{MBH}$ in cockerels; $\boldsymbol{b}$ ) effect of the absence of calcium ions in ACSF on the $56 \mathrm{mM}$ potassiuminduced release of $\mathrm{CLHRH}-\mathrm{I}$ by incubated $\mathrm{MBH}$ in cockerels. Bars represent the mean increase in cLHRH-I concentration, ie the difference between the release elicited by potassium and the basal release measured in the immediately preceding fraction. Values are mean $\pm \operatorname{sem}(n=4)$.
ACSF considerably reduced the $56 \mathrm{mM}$ potassium-induced release of $\mathrm{CLHRH}-\mathrm{I}$. The 1.5-fold increase in the concentration observed in this group was not significant (fig 2b).

\section{Effect of EAA on the release of $C L H R H-I$ in vitro}

Incubation of $\mathrm{MBH}$ in the presence of 100 $\mu \mathrm{M}$ GLU and $100 \mu \mathrm{M}$ NMDA resulted in a 10-fold $(P<0.001)$ and a 4 -fold $(P<0.01)$ increase in the release of CLHRH-I, respectively (fig 3 ).

NMDA elicited a dose-related increase in the secretion of CLHRH-I (fig 4a). The first significant $(P<0.001)$ increase was obtained with the $10 \mu \mathrm{M}$ dose, which multiplied the secretion by 4 . The release elicited by the $100 \mu \mathrm{M}$ dose was very pronounced and was increased more than 10-fold. The stimulation of the release of CLHRH-I in the presence of KA also showed a dose-dependent profile (fig 4b). The response was, however, of much lesser amplitude than that with NMDA, and the highest dose used (100 $\mu \mathrm{M})$ only elicited a 2-fold increase in the secretion.

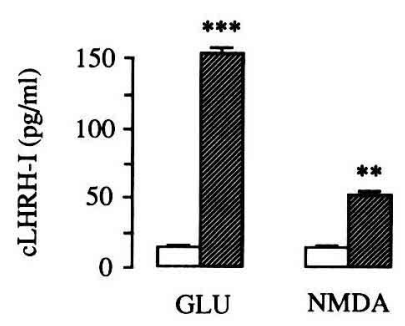

Fig 3. Effect of $100 \mu \mathrm{M} \mathrm{GLU}$ and $100 \mu \mathrm{M}$ NMDA on the release of $\mathrm{CLHRH}-\mathrm{I}$ by incubated $\mathrm{MBH}$ in cockerels (white bars: basal release; striped bars: release in the presence of GLU or NMDA). Values are mean $\pm \operatorname{sem}(n=4) .{ }^{* *} P<0.01 ;{ }^{* \star *} P<0.001$ compared with basal release. 


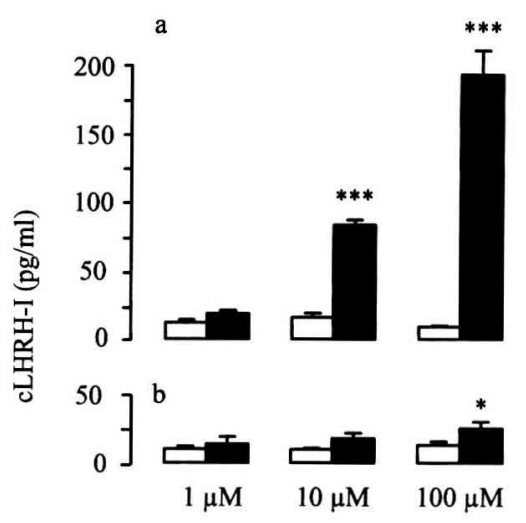

Fig 4. Effect of increasing does of NMDA (a), and $K A$ (b) on the release of cLHRH-I by incubated $\mathrm{MBH}$ in cockerels (white bars: basal release; black bars: release in the presence of the EAA). Values are mean $\pm \operatorname{sem}(n=4) .{ }^{*} P<0.05 ;{ }^{* * *} P<$ 0.001 compared with basal release).

\section{DISCUSSION}

As no release of $\mathrm{CLHRH}-\|$ could be detected by $\mathrm{MBH}$ in vitro (Katz et al, 1990; and our preliminary work), the $20 \%$ cross-reactivity of our assay with cLHRH-II is not an obstacle to its use for in vitro experiments on chicken MBH. Furthermore, no cross-reactivity was found with the following other hypothalamic peptides: leu- and metenkephalin, TRH and CRF. Moreover, the high sensitivity of this assay makes it suitable for the measurement of cLHRH-I in vitro.

The ability of incubated $\mathrm{MBH}$ to release $\mathrm{CLHRH}-\mathrm{I}$ in response to a depolarization in a dose-dependent manner, and to respond to a second depolarization with a comparable magnitude, evidenced the good viability of the tissue in the incubation conditions used. Moreover, the necessity of the presence of calcium ions in the incubation medium for a response to occur showed that this release answers to the physiological mechanisms of neural secretion (Smith and Augustine, 1988).
Of the neurotransmitters known to exert an influence on the secretion of $\mathrm{LHRH}$, EAAs have been shown to increase plasma concentrations of LH (Gay and Plant, 1987; Ondo et al, 1988) and agonists to stimulate the release of $\mathrm{LHRH}$ by hypothalamic tissue of rats in vitro (Bourguignon et al, 1989; Lopez et al, 1992). The use of EAAs in our incubation system allowed us to give first evidence of a similar effect on the secretion of CLHRH-I in the cockerel. The endogenous amino acid, GLU, stimulated the secretion significantly, and proved the most powerful of the 3 agonists that we used. The response elicited was 3 times that elicited by NMDA for the same dose. The effects of the 2 agonists NMDA and KA proved to be dose related, but the effect on KA receptors was shown to be limited. Our results suggest that the action on the NMDA receptor is predominant. Indeed the $10 \mu \mathrm{M}$ dose quadrupled the secretion of CLHRH-I for NMDA, while the maximum dose employed $(100 \mu \mathrm{M})$ only doubled the secretion for $\mathrm{KA}$. This finding is in agreement with that of Bourguignon et al (1989) that NMDA is more potent than $\mathrm{KA}$ in eliciting the release of $\mathrm{GnRH}$ by incubated hypothalimi in the rat. However, the specificity of these effects in the chicken has to be further documented by the use of antagonists.

In conclusion, our static incubation system coupled to the radioimmunoassay proved to be suitable for the study of CLHRH-I release by cockerel $\mathrm{MBH}$. We were thus able to bring first evidence of the stimulatory action of EAAs on the secretion of CLHRH-I in the cockerel and hence of their possible involvement in the control of reproduction through modulation of $\mathrm{LH}$ release in this species.

\section{ACKNOWLEDGMENTS}

We thank FJ Cunningham and RT Gladwell, who helped us develop the incubation technique, and MF Scheller for her technical assistance with incubations and radioimmunoassays. 


\section{REFERENCES}

Bourguignon J, Gérard A, Franchimont $P$ (1989) Direct activation of gonadotropin-releasing hormone secretion through different receptors to neuroexcitatory amino acids. Neuroendocrinology 49, 402-408

Caraty A, Locatelli A (1988) Effect of time after castration on secretion of $\mathrm{LH}-\mathrm{RH}$ and $\mathrm{LH}$ in the ram. J Reprod Fert 82, 263-269

Fraser H, Gunn A, Jeffcoate S, Holland D (1974) Preparation of antisera to luteinizing hormone releasing factor. J Endocrinol 61 , ix-x

Gallardo E, Ramirez V (1977) A method for the superfusion of rat hypothalami: secretion of luteinizing hormone-releasing hormone $(\mathrm{LH}$ RH). Proc Soc Exp Biol Med 155, 79-84

Gay VP, Plant TM (1987) N-methyl-D-aspartate elicits hypothalamic gonadotropin-releasing hormone relase in prepubertal male rhesus monkeys. Endocrinology 120, 2289-2296

Józsa R, Mess B (1982) Immunohistochemical localization of the luteinizing hormone-releasing hormone (LHRH)-containing structures in the central nervous system of the domestic fowl. Cell Tissue Res 227, 451-458

Katz I, Millar R, King J (1990) Differential regional distribution and release of two forms of gonadotropin-releasing hormone in the chicken brain. Peptides 11, 443-450

King J, Millar R (1982a) Structure of chicken hypothalamic luteinising hormone-releasing hormone. I. Structural determination on partially purified material. $J$ Biol Chem 257 , 10722-10728

King J, Millar R (1982b) Structure of chicken hypothalamic luteinising hormone-releasing hormone. II. Isolation and characterization. $J$ Biol Chem 257, 10729-10732

Knight P (1983) Variations in hypothalamic luteinizing hormone-releasing hormone content and release in vitro and plasma concentrations of luteinizing hormone and testosterone in developing cockerels. J Endocrinol 99, 311-319

Kuenzel W, Blhäser S (1991) The distribution of gonadotropin-releasing hormone $(\mathrm{GnRH})$ neurons and fibers throughout the chick brain (Gallus domesticus). Cell Tissue Res 264, 481-495
Levine J, Ramirez V (1986) Measurement of neuropeptide release: in vitro and in vivo procedures. Methods Enzymol 24, 466-494

López F, Donoso A, Negro-Vilar A (1992) Endogenous excitatory amino acids and glutamate receptor subtypes involved in the control of hypothalamic luteinizing hormonereleasing hormone. Endocrinology 130 , 1986-1992

Mikami SI, Yamada S, Hasegawa Y, Miyamoto K (1988) Localization of avian LHRH-immunoreactive neurons in the hypothalamus of the domestic fowl, Gallus domesticus, and the Japanese quail, Coturnix coturnix. Cell Tissue Res $251,51-58$

Miyamoto K, Hasegawa $\mathrm{Y}$, Nomura N, Igarashi M, Kangawa M, Matsuo $\mathrm{H}$ (1984) Identification of the second gonadotropin-releasing hormone in the chicken hypothalamus: evidence that gonadotropin secretion is probably controlled by two distinct gonadotropin-releasing hormones in avian species. Proc Natl Acad Sci USA 81, 3874-3878

Ondo J, Wheeler D, Dom R (1988) Hypothalamic site of action for $\mathrm{N}$-methyl-D-aspartate (NMDA) on LH secretion. Life Sci 43, 22832286

Rotsztejn W, Charli J, Pattou E, Epelbaum J, Kordon $C$ (1976) in vitro release of luteinizing hormone-releasing hormone (LHRH) from rat mediobasal hypothalamus: effects of potassium, calcium and dopamine. Endocrinology 1663-1666

Salacinski P, Hope J, McLean C, Clement-Jones $V$, Sykes J, Price J, Lowry P (1979) A new simple method which allows theoretical incorporation of radio-iodine into proteins and peptides without damage. $J$ Endocrinol $81,131 \mathrm{P}$

Smith SJ, Augustine CJ (1988) Calcium ions, active zones and synaptic transmitter release. Trends Neurosci 11, 458-464

Sterling R, Sharp P (1982) The localisation of $\mathrm{LH}-\mathrm{RH}$ neurons in the diencephalon of the domestic hen. Cell Tissue Res 222, 283-298

Wibullaksanakul S, Handelsman D (1991) Hypothalamic gonadotropin-releasing hormone secretion: methodological aspects of in vitro systems. I Neuroendocrinol 3, 185192 